\title{
Determinants of foreign direct investment in the Zimbabwean mining sector
}

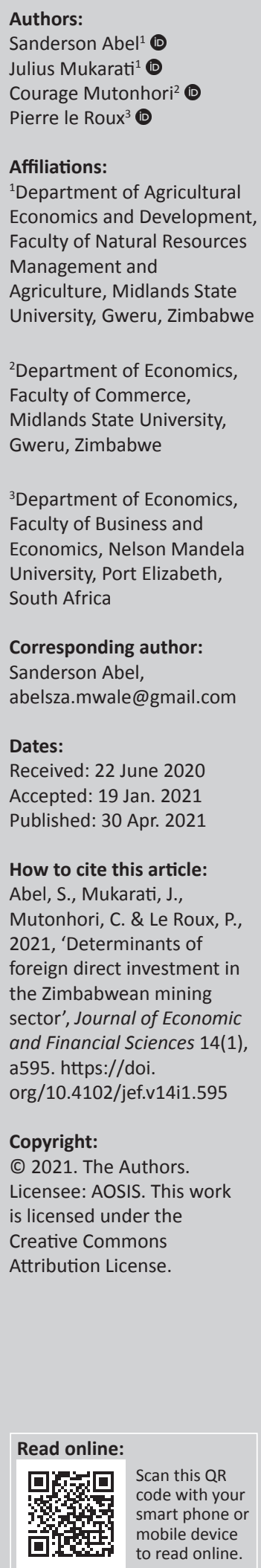

Orientation: The mining industry being the main source of foreign currency for economy is the backbone of the Zimbabwean economy. The performance of the sector has been dwindling of late. The downturn has been attributed to outdated equipment, lack of foreign currency to import modern equipment, expensive new technology and general macroeconomic problems.

Research Purpose: Given the problems being faced by the sector, this article investigated the determinants of foreign direct investment (FDI) into the mining sector (MS).

Motivation for the study: Given the mining sector's contribution to the economy, understanding what motivates corporates to invest into the sector is of interest to the policy makers. The decline in investment is a cause of concern.

Research approach and method: The study employed the autoregressive distributed lag (ARDL) method to evaluate the determinants of FDI into the Zimbabwean MS.

Main Findings: The results show that FDI in the MS is driven by gross domestic product (GDP), wage rates, inflation, interest rates and openness in the long term. In the short run, GDP, wage rates, inflation, interest rates and openness have a significant effect on FDI into the MS.

Practical implications: This study recommends that government should put in place pro-growth policies in order to attract more foreign investors. The monetary policy should ensure interest rates are maintained very low to allow local resources to complement FDI.

Contribution: The study contributes to the literature on determinants of FDI in the mining sector.

Keywords: foreign direct investment (FDI); economic growth; mining sector (MS); autoregressive distributed lag (ARDL); gross domestic product (GDP); wage rates; inflation; interest rates; openness; Zimbabwe.

\section{Introduction}

The Zimbabwean economy has witnessed a tremendous shift from agro-based to mineral resource-depended economy (Scoones 2013). The economic policies that have been initiated in the country have seen the prioritisation of the mining sector (MS) (Zimbabwe Environmental Law Association 2016). The Zimbabwean economy is rich in mineral resources, boasting a number of minerals, which include diamonds, platinum, gold, coal, asbestos, iron, nickel, ferrochrome and chrome to name but a few (Chamber of Mines of Zimbabwe 2016).

The contribution of the MS to total exports averaged 40\% of total exports (Hawkins 2009). The MS is a major foreign currency generator although its contribution has been declining in the recent years (Malinga 2018). There is great potential for the economy to contribute heavily to sustainable economic growth and development, a panacea to poverty eradication and employment creation. The declining contribution of the MS is attributed to corruption, mismanagement, economic sanctions and policy inconsistency (Malinga 2018). Foreign direct investment (FDI) into the MS has been declining over the past 25 years as a result of economic instability, retarded growth, high interest rates and wage fluctuations in the economy (Muzurura 2015).

The decline in FDI into the MS in Zimbabwe is a cause of concern given that the local capital markets are facing serious scarcity of resource whilst the economy is struggling to generate enough foreign currency. This situation is prevailing as a number of minerals are being discovered in the country. Worse still a number of mines have been closing at the time mineral prices on the world market have been at an all-time high. In the light of these developments, the study explores the major determinants of FDI in the MS in Zimbabwe. The research will contribute towards the 
ongoing debate on the determinants of FDI in the MS in Zimbabwe. An understanding of those factors will assist Zimbabwean policymakers to construct and implement strategies for attracting FDI in the MS and solve current challenges of abject poverty, low industrial productivity, high unemployment and lethargic growth.

\section{Background of the study}

Foreign direct investment is an investment made by a firm or individual in one country into business interests located in another country. Foreign direct investment takes place when an investor establishes foreign business operations or acquires foreign business assets in a foreign company. Tapera (2016) defined FDI as a measure of foreign ownership of productive assets, such as factories, mines and land whereas mining is the extraction of valuable minerals or other geological materials from the Earth, usually from an ore body, lode, vein, seam, reef or placer deposit (Malinga 2018). These deposits form a mineralised package that is of economic interest to the miner.

Zimbabwe got its independence in 1980 and the new government embarked on policies that rectify the imbalance that favoured the white settlers with regard to mining rights. The law that governs mining in Zimbabwe is the Mines and Minerals Act (ch. 21:05) (Chamber of Mines of Zimbabwe 2015). One major weakness of this Act is that it gives the Minister of Mines and Mining Development excessive power to make unilateral decisions over the country's prospects of mineral production and this has far outreaching and dire economic and social consequences (Matsika 2010). The Act needs to be refined and purified for it to bring a success story to Zimbabwe because the sector is important to the country's economy. Reserves of gold, platinum group metals and diamonds combine to form Zimbabwe's largest export and thus are the primary source of foreign currency. The country is struggling to maintain sufficient foreign currency reserves, whilst also desperately requiring investment and expansion to compete (Chamber of Mines of Zimbabwe 2016). Stringent regulations have discouraged many potential investors from pursuing opportunities in Zimbabwe's MS in the past. The country is fully enmeshed in a foreign currency crisis that emerged in the late 2018, whilst the government appears ready to make some big changes because it has already approved the adoption of a new currency, in the hopes of stabilising the exchange rate with the US dollar (ZCDCO 2019).

According to the Minerals Marketing Corporation of Zimbabwe (MMCZ) (2019), Zimbabwe is currently experiencing declining ore grades, lack of FDI, heightened sovereign, critical infrastructure shortage, balancing national economic and investment interest (policy), rising cost of production, innovation imperative and finding funding. Furthermore, rising exchange rates, rapidly changing monetary policies, along with the lack of willing sellers of foreign currency, have negatively impacted FDI in the sector. Currently the sector has been experiencing declining interest

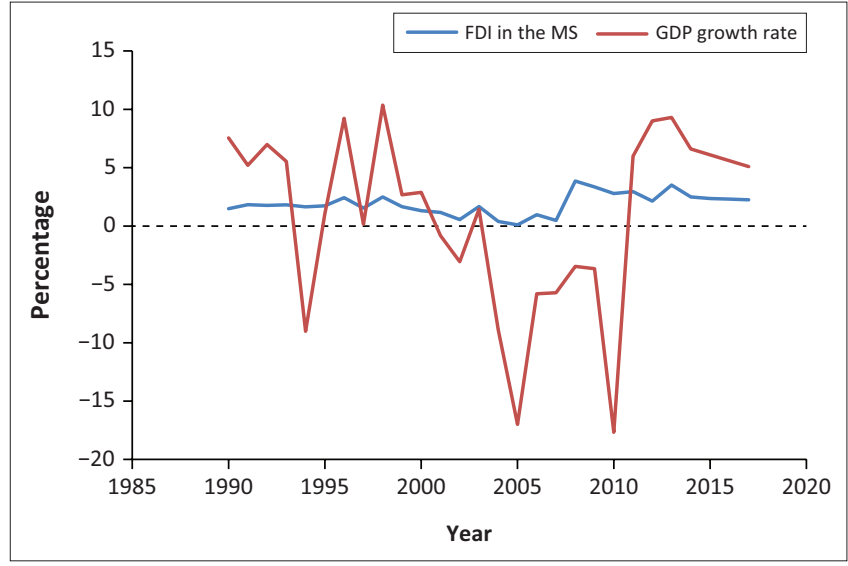

$\mathrm{DI}$, foreign direct investment; MS, mining sector; GDP, gross domestic product. FIGURE 1: Foreign direct investment growth and economic growth (1990-2017).

in the number of foreign companies interested in directly investing in Zimbabwean mining operations. It seems as if international business is waiting for monetary policy clarification regarding how invested capital and profit earnings will be converted back into foreign currency and repatriated to the home countries. The shortage of willing sellers within the interbank formal sector is mostly pronounced because informal sector takes a big portion of the country's economic activities (Zimbabwe Independent 2014).

Furthermore, most mining operations suffer from undercapitalisation and are, therefore, in need of recapitalisation through financial injections. According to the ZMDC (2019), most mines are currently operating slightly above $50 \%$ of their designed capacities because of lack of finances for recapitalisation. Mangudhla (2016) noted that most mining companies face financial constraints and old dump retreatment.

Figure 1 shows the FDI growth in the MS between 1990 and 2017 and the economic growth. Foreign direct investment growth in the MS has been relatively stable compared with gross domestic product (GDP) growth rate; although not visibly clear, ad the trends of the two seem to largely behave in a similar way to the extent that both curves from 2014 and thereafter are dwindling.

\section{Literature review}

This section will review prior studies on the determinants of FDI in the MS.

Muzurura (2019) studied the determinants of FDI in Zimbabwe for the period 1980-2011. This study utilised a multivariate regression method with time series data. The study established that FDI was driven by gross fixed capital formation, economic stability, trade openness, corruption, political instability, poor governance, weak export competitiveness and inconsistent government policies. The study recommended that the government should ensure that there is economic stability and conducive investment climate, which boosts investment, export competitiveness and fixed capital formation. 
In a similar study, Gochero (2018) evaluated the factors affecting FDI in the Zimbabwean MS during the period 2005-2014. This study employed panel regression method with random effects over 14 mineral resources. The study failed to establish a link between mineral price and output as drivers of the FDI into the sector. The study recommended that policies that encourage investment and recapitalisation in the MS should be crafted. The study also recommended that there should be level playing field for both foreigners and local firms.

Tapera (2016) reviewed various strategy documents adopted by African governments in an effort to lure FDI in order to attain sustainable development. This study further compared foreign direct inflows amongst Zimbabwe, South Africa and Mozambique and found that policies including indigenisation and economic empowerment policy, introduction of special economic zones, and introduction of various incentives for foreign investors were important for creating a conducive and safe environment for foreign investors.

O'Meara (2015) investigated the major determinants of FDI on a cross-country basis. The study drew its sample from both developed and developing countries at a static time period. The study employed ordinary least squares (OLS) method and established that variables relating to the size and scale of economic activity were a driver of FDI into the different countries. The study also found that tax incentives, human capital and economic freedom were not important in attracting FDI.

Kariuki (2015) evaluated the drivers of FDI into African countries using the least squares dummy variable (LSDV) approach. This study found that high economic risk negatively and significantly influenced FDI into Africa. Political and financial risk did not have a bearing on the drivers of FDI. Stock market performance had a positive and significant impact on FDI flows. The study further found that FDI persists over time, implying that previous period flow had an impact on the flows in the succeeding period.

Anyanwu (2012) studied the drivers of FDI in 35 African countries for the period 1996-2008. This study revealed that market size and FDI flow had a positive significant correlation. Openness of trade positively impacted FDI flows whilst higher financial development negatively affected FDI inflows.

Okafor (2014) studied the factors driving FDI on a sample of Sub-Saharan Africa and North African countries. He used the pooled OLS method and the fixed-effects method. The results established that profitability, corruption, trade openness and strategic assets were the main drivers of FDI in SSA.

Azam and Luckman (2010) employed OLS approach to analyse the determinants of FDI in India, Indonesia and Pakistan for the period 1971-2005. The findings confirmed that government consumption, debt and tax had an inverse influence on FDI, whilst market size, domestic investment and openness found to be positive. However, inflation rate has been found to be insignificant with unexpected positive signs.

Tole and Koop (2011) studied the factors that motivate major gold firms to determine location on where to set up their operations. This study evaluated economic, political, regulatory, infrastructure and investment risk variables. The study established that the major factors considered were low level of corruption, conduciveness of economic environment for business, efficiency of institutions, advantageous tax codes and transparent laws. Tight environmental regulation also attracted gold producers.

Cheng and Kwan (2002) studied factors affecting FDI in the mining and quarrying, manufacturing and construction using pooled regression for 13 sectors in China and nine sectors in the Guangdong province. The study spanned from 1977 to 2002. The major drivers of investment in the MS were found to be market size, infrastructure, policy designations, labour wage and political instability

Andreia (2011) undertook a sectorial study on the determinants of Portuguese FDI using OLS for the period 1980-2009. This study established that exchange rates, wages and taxation had a negative effect on FDI. On the other hand, openness and GDP positively impacted FDI in the MS.

Siphambe (2004) established that stable political environment, stable macroeconomic policies and exchange rates are significant determinants of FDI inflows. He also found that educated human capital and reduced crime rates attracted FDI inflows in Botswana.

Hess (2000) evaluated the investment climate in Southern Africa. He employed a survey-type research interviewing a number of corporations who wanted to invest in the Southern African Development Community (SADC). This study established that lack of transparency, unstable political and economic environment, high taxation, corruption and poor infrastructure were barriers to FDI in theSADC region. Thestudy recommended that governments should create stable political and macroeconomic environment to attract more FDI inflows.

\section{Research methodology}

The present study employed the autoregressive distributed lag (ARDL) method to establish the drivers of FDI into the MS in Zimbabwe. The ARDL is procedural and involves a number of steps.

The first step to examine the short- and long-run relationships between FDI inflows and its determinants is to test for stationarity of the variables in question. This is meant to avoid the problem of spurious regression results in time series analysis. Under the ARDL method, it is important to ensure that none of the variables are integrated of order $I(2)$ and above. The method is not applicable once variables are integrated of order I(2) and above. The unit root test was carried out using augmented Dickey-Fuller (ADF) unit root test. 
Once the study establishes that none of the variables are integrated of order higher than I(1), the ARDL bounds testing approach to cointegration is used to determine the existence of long-run equilibrium relationships between FDI and its determinants. This will consist of estimating the dynamic unrestricted error-correction model using OLS by taking each variable as the dependent variable in turns. In doing so, the short-run dynamics are integrated with the long-run equilibrium; therefore, long-run information is retained:

$$
\begin{aligned}
\Delta F D I_{t}= & \alpha_{0}+\alpha_{t} T+\sum_{h=1}^{a} \delta_{n} \Delta F D I_{t-1}+\sum_{i=0}^{b} \delta_{1} \Delta X_{t-1}+ \\
& \beta_{1} F D I_{t-1}+\beta_{2} X_{t-1}+\varepsilon_{t}
\end{aligned}
$$

where $\Delta$ represents the first difference operator, $\alpha_{0}$ is the drift component in the equation, $T$ is the time trend, $F D I_{t}$ is the dependent variable (FDI), $X_{t}$ is a vector of determinants (composed of openness of the country, interests rate, inflation rate, wage, GDP and growth rate education [tertiary education]), $\delta s$ are the short-run coefficients and $\beta$ s are the long-run multipliers and represent the error terms that are assumed to be independent and identically distributed.

The existence of a long-run equilibrium relationship between FDI and its determinants is tested through a joint F-test on the one period lagged level variable (Pesaran, Shin and Smith 2001). The hypotheses to be tested are:

$H_{0}: \beta_{1}=\beta_{2}=0$

$H_{1}: \beta_{1} \neq \beta_{2} \neq 0$.

Should the F-statistics exceed the upper bounds of the critical value, $I(1)$, then we may reject the null hypothesis of no cointegration, concluding that the variables contained in the models share meaningful long-run relationships (Pesaran et al. 2001). However, if the F-statistics are inferior to the lower bounds of the critical value, $I(0)$, we fail to reject the null hypothesis of no cointegration amongst the variables and conclude that the variables being tested do not share a significant long-run relationship (Pesaran et al. 2001). Furthermore, if the calculated F-statistics fall in between the upper and lower bounds of the critical values, we can neither accept nor reject the null hypothesis of no cointegration, ultimately leading to inconclusiveness of the results (Pesaran et al. 2001). Once the long-run relationship amongst the variables is established, a short-run error-correction models will be estimated.

\section{Definition and justification of variables}

Foreign direct investment in the MS (FDIM) is a measure of foreign ownership of productive assets. It is the dependent variable and shall consist of capital inflows in the MS per annum. The dependent variable is formed up with FDI inflow destined for the MS only.

\section{Economic growth (gross domestic product)}

It is the economist's yardstick by which to evaluate the economic performance, that is, an increase or decrease in the market value of all goods and services produced within the boundaries of a nation regardless of nationality of the people who produce them over time. It is preferred ahead of the gross national product (GNP) that considers outside production, which does not take into account a county's borrowing decisions. Changes in GDP are considered a key variable to explain the direction of FDI over a period of time, hence a proxy for market size. Foreign investors are likely to consider the target country's income, output and production capacity before they move in. These factors will unduly affect market size (Tapera 2016). Theoretically, the level of FDI is positively related to the size of foreign market. Gross domestic product growth rate is expected to be positively related to FDI (Muzurura 2019).

\section{Labour costs (wage)}

It is the reward (wages and salaries) for labour in the MS. The labour costs in MS should have a negative impact on the level of FDI as firms wanted to invest where costs of productions are low (Andreia 2011). All rational firms aim to maximise profits and alternatively to minimise costs of production, which is one and the same thing. Lower wage rate should be more attractive to foreign companies. Average wage rate in the MS is a proxy for labour cost.

\section{Inflation}

Inflation (INF) is defined as the general rise in the price level or the reduction in the purchasing power of currency. We are going to use consumer price index (CPI) as a proxy for inflation, inflation reduces the return on investment and this has a negative impact on FDI, and inflation will have a negative expected sign (Matsika 2010). Dabla-Norris et al. (2010) found a positive impact of a low inflation environment on FDI inflows. Abartli (2011) found out that the inflation performance of emerging market economies, measured by the share of countries that had less than $10 \%$ annual inflation, improved significantly during the sample period.

\section{Openness of the country}

The ratio of exports plus imports to GDP (openness [OP]) is used to determine FDI inflows in the MS. Tapera (2016) and Dabla-Norris et al. (2010) reported a strong positive effect of openness on FDI inflows. Export is a measure of the targeted country's exporting capacity and global demand for its output. Investors may plan on exporting manufactured output from the host country and only sell a small proportion of output to the local market. Most multinational companies take advantage of cheap labour and export much of the production back to its origin market. One of the key determinants of FDI inflows is the export orientation and competitiveness of an economy. As noted by other studies, the effect of export orientation on FDI inflows may be ambiguous because it would depend on whether FDI-related production is meant to serve the export or the domestic market.

\section{Public Expenditure on Education - Human Capital}

The number of educated people is used as the proxy to measure human capital investment. The sign is expected to be positive 
(Cheng \& Kwan 2002), and the greater the number of higher tertiary education, the higher is the productivity and hence high productivity attracts more FDIs. As a result of data limitations, this variable serves as a proxy measure of how skilled and educated the workforce of the reporting country is. We also obtain data on the number of individuals who have attained tertiary education as a further proxy for human capital. Barro and Lee (2010) constructed an instrument that uses the average years of school attainment to measure the level of education and its impact on attracting FDI.

\section{Interest rates}

It is the reward for partying with liquidity that is the cost of capital. The coefficient is expected to be either positive or negative. The relationship can be positive because these are not domestic investors, they are foreign investors, and the interest rates (INT) do not influence their decision to invest (Onyeiwu 2000). However, it can be negative - the higher the interests, the lower the investment because of macroeconomic and political instability (Dabla-Norris et al. 2010).

To find the relationship between variables, this research employed OLS method to estimate the model of the determinants of FDI in the MS. However, for OLS estimates to be BLUE (best linear unbiased estimates), basic assumptions of OLS should hold. These assumptions are normality and homoscedasticity of the error term, no multicollinearity, no autocorrelation and no model misspecification. On regression analysis, the following tests are done: stationary, multicollinearity and diagnostic test. Diagnostic test includes normality, homoscedasticity, autocorrelation, goodness-of-fit $R$-squared and model specification test.

The present study used secondary data collected from the World Bank database and Zimbabwe Statistical Agency (ZIMSTATS) from 1990 to 2019. All variables are given in log form with the exception of those given in percentage form. Gross domestic product growth rate FDI, wages and education figures are available at ZIMSTATS, whilst imports, exports and inflation figures are available at World Bank database.

\section{Results presentation and analysis}

The descriptive statistics for the variables used to estimate the FDI into the MS regression are presented in Table 1.

Table 1 shows that the variables do not have large dispersion as shown by the standard deviation save for GDP, wage and

TABLE 1: Descriptive statistics.

\begin{tabular}{|c|c|c|c|c|c|}
\hline Variable & Observation & Mean & SD & Minimum & Maximum \\
\hline FDI & 30 & 1.903916 & 0.9398558 & 0.1000226 & 3.859263 \\
\hline GDP & 30 & 0.881901 & 7.570922 & -17.6689 & 10.3607 \\
\hline $\mathrm{HC}$ & 30 & 4.473289 & 0.4312225 & 3.893706 & 4.984568 \\
\hline Wage & 30 & 508.3107 & 152.1574 & 265.2 & 780 \\
\hline INFL & 30 & 8250332 & $4.37 e+07$ & 3 & $2.31 \mathrm{e}+08$ \\
\hline INT & 30 & 64.79643 & 89.19418 & 7.73 & 340 \\
\hline $\mathrm{OP}$ & 30 & 1.868675 & 0.1011787 & 1.644442 & 1.991725 \\
\hline
\end{tabular}

SD, standard deviation; FDI, foreign direct investment; GDP, gross domestic product; $\mathrm{HC}$, education expenditure; INFL, inflation; INT, interest rates; OP, openness of the country. interest rate. This means that there is no wide dispersion amongst the variables of interest.

In order to avoid estimating a spurious regression, the study evaluated the stationarity of the variables. This was meant to check on the level of integration of the different variables and hence to allow the estimation of the cointegration equation. The results are presented in Table 2 .

After performing the ADF test, it was found that GDP, inflation and interest rate were stationary in levels, whilst the rest of the variables became stationary after differencing.

In an effort to avoid the problems of multicollinearity, a correlation matrix was computed. The results are shown in Table 3.

Based on a rule of thumb, a correlation coefficient of greater than 0.8 can lead to severe multicollinearity. Table 3 shows that the variables are not strongly correlated, and hence the chance of multicollinearity is reduced.

Table 4 shows that the long-term cointegration exists amongst the variables. This is evidenced through the F-statistic, which is greater than the upper bound $I(1)$. The F-statistic tests the joint null hypothesis that the coefficients of the lagged level variables are zero, that is, no long-run relationship exists between them. The importance of this result is that the ARDL model is appropriate to examine the FDI model in both short run and long run.

TABLE 2: Unit root test.

\begin{tabular}{lc}
\hline Variables & Order of integration \\
\hline FDI & $I(1)$ \\
GDP & $I(0)$ \\
HC & $I(1)$ \\
Wage & $/(1)$ \\
INFL & $I(0)$ \\
INT & $I(0)$ \\
OP & $I(1)$ \\
\hline
\end{tabular}

FDI, foreign direct investment; GDP, gross domestic product; $\mathrm{HC}$, education expenditure; INFL, inflation; INT, interest rates; OP, openness of the country.

\begin{tabular}{lccccccc}
\multicolumn{7}{l}{ TABLE 3: Correlation matrix. } \\
\hline Correlation & FDI & GDP & HC & WAGE & INFL & INT & OP \\
\hline FDI & 1.0000 & - & - & - & - & - & - \\
GDP & 0.3876 & 1.0000 & - & - & - & - & - \\
HC & 0.3741 & -0.1810 & 1.0000 & - & - & - & - \\
Wage & -0.3389 & 0.4078 & -0.7865 & 1.0000 & - & - & - \\
INFL & 0.1840 & -0.4802 & 0.2212 & -0.3066 & 1.0000 & - & - \\
INT & -0.0322 & -0.6051 & 0.4271 & -0.5964 & 0.5655 & 1.0000 & - \\
OP & 0.3680 & -0.0553 & 0.7374 & -0.6478 & 0.1691 & 0.2283 & 1.0000 \\
\hline
\end{tabular}

$\mathrm{FDI}$, foreign direct investment; GDP, gross domestic product; $\mathrm{HC}$, education expenditure; INFL, inflation; INT, interest rates; OP, openness of the country.

TABLE 4: Autoregressive distributed lag bound testing cointegration.

\begin{tabular}{lcccc}
\hline Test statistic & Value & Significance (\%) & $/(\mathbf{0})$ & I(1) \\
\hline- & - & 10 & 2.12 & 3.23 \\
F-statistic & 10.8652 & 5 & 2.45 & 3.61 \\
$K$ & 6 & 2.5 & 2.75 & 3.99 \\
- & - & 1 & 3.15 & 4.43 \\
\hline
\end{tabular}


Once we established that a long-run cointegration relationship existed, Equation (1) was estimated using the following $\operatorname{ARDL}(2,1,2,2,0,0,2)$ specification. The results obtained by normalising on FDI in the long run are reported in Table 5.

The results show that FDI in the MS in the long run is determined by GDP, wage, inflation, interest rate and openness. Gross domestic product has got a positive coefficient, implying that FDI and GDP are positively related. A unit change in GDP will result in an increase in the level of FDI. Positive coefficient of GDP is very much supported by various empirical observations because the level of a country's production reveals its market size and well-being that are often admired and desired by foreign direct investors. A number of studies support the result that GDP growth rate is positively related to FDI (Muzurura 2019; Tapera 2016).

Wages and FDI are inversely related. This implies that a rise in wage rate will deter FDI. A high wage rate will make the cost of production high and it should also be noted that multinational companies are rational and they aim to maximise profits and minimise costs, which is one and the same thing (Andreia 2011). This supports the result by arguing that e-labour costs should have a negative impact on the level of FDI as firms wanted to invest where costs of productions are low.

Surprisingly, inflation was found to be positively related with FDI. This means that inflation moves in the same direction with FDI; this could be possible if a nation is experiencing money illusion whereby employees fail to

TABLE 5: Coefficient estimation results.

\begin{tabular}{|c|c|c|}
\hline \multirow[t]{2}{*}{ Variable } & \multicolumn{2}{|c|}{ Dependent variable (FDI) } \\
\hline & Coefficient & $P$-value \\
\hline \multicolumn{3}{|l|}{ Long-run results } \\
\hline GDP & 0.1285 & $0.0017 * * *$ \\
\hline INFL & $3.5 \mathrm{E}-07$ & $0.0036 * * *$ \\
\hline INT & -0.0092 & $0.0351 * *$ \\
\hline $\mathrm{OP}$ & -4.4025 & $0.0903 *$ \\
\hline Wages & -0.0067 & $0.0189 * *$ \\
\hline $\mathrm{HC}$ & 0.4450 & 0.1921 \\
\hline \multicolumn{3}{|l|}{ Short-run results } \\
\hline C & 9.0221 & $0.0000 * * *$ \\
\hline $\mathrm{D}(\mathrm{FDIM}(-1))$ & -0.2482 & $0.0085 * * *$ \\
\hline $\mathrm{D}(\mathrm{GDP})$ & 0.0707 & $0.0000 * * *$ \\
\hline $\mathrm{D}(\mathrm{INFL})$ & $7.76 \mathrm{E}-08$ & $0.0001 * * *$ \\
\hline $\mathrm{D}(\mathrm{INFL}(-1))$ & $-6.06 \mathrm{E}-08$ & $0.0045 * * *$ \\
\hline $\mathrm{D}(\mathrm{INT})$ & -0.0037 & $0.0037 * * *$ \\
\hline $\mathrm{D}(\mathrm{INT}(-1))$ & 0.0048 & $0.0001 * * *$ \\
\hline $\mathrm{D}(\mathrm{HC})$ & -1.2781 & $0.0771 *$ \\
\hline $\mathrm{D}(\mathrm{HC}(-1))$ & -2.1454 & $0.0141 * *$ \\
\hline CointEq(-1)* & -0.7531 & $0.0000 * * *$ \\
\hline$R$-squared & \multicolumn{2}{|c|}{0.9511} \\
\hline Autocorrelation test & \multicolumn{2}{|c|}{$P$-value $>\mathrm{Chi}^{2}=0.798$} \\
\hline Ramsey reset & \multicolumn{2}{|c|}{$P$-value $>F=0.435$} \\
\hline
\end{tabular}

FDI, foreign direct investment; FDIM, Foreign direct investment in the MS; GDP, gross domestic product; HC, education expenditure; INFL, inflation; INT, interest rates; $\mathrm{OP}$, openness of the country.

$* 10 \%, * * 5 \%, * * * 1 \%$ notice a wage rise caused by inflation forces and completely ignore real wage; henceforth, FDIs can take advantage of this loophole by exchanging the hot currency into local large sums of money. Abartli (2011) and Dabla-Norris et al. (2010) found a positive effect of inflation on FDI.

Interest rates are negatively related to FDI. When interest rates (the cost of funds) increase in the economy, it makes it expensive to borrow on the local market. This reflects the fact that foreign capital should be complemented with local resources. The increase in local funds tends to scare away foreign capital. Usually FDI requires that working capital resources should be accessed locally. The result is supported by Dabla-Norris et al. (2010), who established that the higher interest rate disincentivises foreign direct investors.

The country's openness has a positive effect on FDI at $10 \%$ of significance. This implies that the more the country opens up, the more FDI it can attract. Measures such as $51 \%$ local content had a negative effect on attracting FDI. The results are supported by Tapera (2016) and Dabla-Norris et al. (2010) who reported a strong positive effect of openness on FDI inflows.

The short-run results show that all the variables - GDP, wage, inflation, interest rate and openness - have a significant effect on FDI into the MS. The equilibrium correction coefficient, estimated to be -0.7531 , is highly significant, has the correct sign and implies a fairly high speed of adjustment to equilibrium after a shock. Approximately $75 \%$ of disequilibria from the previous year's shock converge back to the long-run equilibrium in the current year. The regression for the underlying ARDL equation fits well with $R$-squared of $95 \%$ and also passes the diagnostic tests against serial correlation, and functional form misspecification.

\section{Stability test}

The stability of the model is tested using the cumulative sum (CUSUM) square. Figure 2 shows that the CUSUM square is within the standard bound with a significance level of $5 \%$. The CUSUM plot shown in Figure 2 obtained from the recursive estimation of the model indicates stability in the coefficients over the sample period for Zimbabwe.

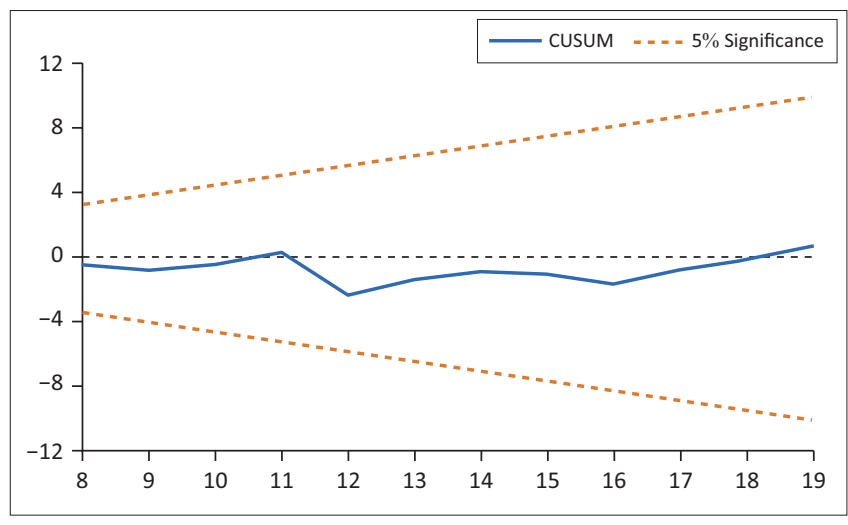

CUSUM, cumulative sum.

FIGURE 2: Stability test. 


\section{Summary and policy recommendation}

This study finds GDP growth as one of the main determinants of FDI in the MS in Zimbabwe. The policy recommendation that come out from this is that efforts should be made to boost the level of economic growth in order to attract more foreign investors because economic growth is a catalyst for FDI. The monetary policy should ensure that interest rates are maintained very low to allow local resources to complement FDI. This also applies to the wages that can act as a disincentive to foreign investors if they are maintained at high level. Overall FDI follows markets where the cost of production is low. The government should strive to put in place proper macroeconomic management, policy consistency, fair treatment of all investors and non-arbitrary involvement in foreign firms.

\section{Acknowledgements Competing interests}

The authors declare that they have no financial or personal relationships that may have inappropriately influenced them in writing this article.

\section{Authors' contributions}

All authors contributed equally to this work.

\section{Ethical considerations}

This article followed all ethical standards for research without direct contact with human or animal subjects.

\section{Funding information}

This research received no specific grant from any funding agency in the public, commercial or not-for-profit sectors.

\section{Data availability}

Data sharing is not applicable to this article as no new data were created or analysed in this study.

\section{Disclaimer}

The views and opinions expressed in this article are those of the authors and do not reflect the official policy or position of any affiliated agency of the authors.

\section{References}

Andreia, A.F.S., 2011, The determinants of FDI in Portugal: A Sectoral Approach Dissertation submitted in partial fulfilment of requirements for the degree of Master of Science in Economics, Catholic University of Portugal, Lisbon.

Anyanwu, C.J., 2012, 'Why does FDI go where it goes? New evidence from African countries', Annals of Economics and Finance 13(2), 425-462.

Arbatli, E.C., 2011, 'Economic policies and FDI inflows to emerging market economies', IMF Working Paper No.11192, 1-25, International Monetary Fund, Washington.
Azam, M. \& Lukman, L., 2010, 'Determinants of Foreign Direct Investment in India, Indonesia and Pakistan: A Quantitative Approach', Journal of Managerial Sciences $4(1), 31-44$

Barro, R.J. \& Lee, J.W., 2010, 'A New Data Set of Educational Attainment in the World, 1950-2010', NBER Working Paper 15902, National Bureau of Economic Research, Cambridge.

Chamber of Mines of Zimbabwe, 2015, State of the mining industry survey: Report on the findings, Chamber of Mines, Harare.

Chamber of Mines of Zimbabwe, 2016, Mining industry: 2016 first quarter performance report, Chamber of Mines, Harare.

Cheng, L.K. \& Kwan, Y.K., 2000, 'What are the determinants of the location of foreign direct investment? The Chinese experience', Journal of International Economics 51(2), 379-400. https://doi.org/10.1016/S0022-1996(99)00032-X

Dabla-Norris, E., Honda, J., Lahreche, A. \& Verdier, G., 2010, FDI flows to low-income countries: Global drivers and growth implications, IMF Working Paper No. 10/133, International Monetary Fund, Washington.

Gochero, P., 2018, 'Econometric analysis of foreign direct investment in the Zimbabwean mining sector 2005-2014', Theoretical Economics Letters 8(1) 3157-3177. https://doi.org/10.4236/tel.2018.814196

Hawkins, T., 2009, The mining sector in Zimbabwe and its potential contribution to recovery: United Nations development programme, comprehensive economic Recovery in Zimbabwe, Working Paper Series, viewed 27 October 2019, from www.cryptone.org/kimberly/kimberly-003.pdf.

Hess, R., 2000, Constraints on foreign direct investment. Gaining from trade in Southern Africa: Complementary policies to underpin the SADC Free Trade Area, Macmillan, London.

Kariuki, C., 2015, 'The determinants of foreign direct investment in the African Union', Journal of Economics, Business and Management 3(3), 346-351. https://doi. org/10.7763/JOEBM.2015.V3.207

Malinga, W., 2018, 'From an agro-based to a mineral resource- dependent economy: A critical review of the contribution of mineral resources to the economic development of Zimbabwe', Forum for Development Studies 45(1), 71-95. https:// doi.org/10.1080/08039410.2017.1378711

Mangudhla, T., 2016, Zimbabwe: Mining sector slow down spells doom for economy viewed 28 October 2019, from www.allafrica.com/stories/201602050326.htm .

Matsika, B., 2010, Mining and minerals special focus: Mining Zimbabwe, viewed 27 October 2019, from www.howwemadeitinafrica.com/a-closer-look-at-zimbabwesmining-sector/.

Muzurura, J., 2015, 'Determinants of FDI in Zimbabwe: What factors matters?', Research in Business and Economics Journal 1(1), 23-46.

Muzurura, J., 2019, 'Foreign direct investment in Zimbabwe: The role of uncertainty, exports, cost of capital, corruption and market size', The Economics and Finance Letters Conscientia Beam 6(1), 9-24. https://doi.org/10.18488/journal.29.2019.61.9.24

Okafor, G.C., 2014, 'Determinants of FDI into Sub-Saharan African and its impact on economic growth', Unpublished PhD thesis, University of Bournemouth.

O'Meara, G., 2015, 'Examining the determinants of foreign direct investment', Undergraduate Economic Review 11(1), 529-540.

Onyeiwu, S., 2000, 'Foreign direct investment, capital outflows and economic development in the Arab world', Journal of Development and Economics Policies 22(1), 27-57.

Pesaran, M.H., Shin, Y. \& Smith, R.J., 2001, 'Bounds testing approaches to the analysis of level relationships', Journal of Applied Econometrics 16(1), 289-326.

Scoones, I., 2013, Zimbabwe's agricultural sector goes from 'bread basket to basket case' or is it again a bit more complicated, viewed 26 October 2019, from https://zimbabweland.wordpress.com/2013/09/23/zimbabwes-agriculturalsector-goes-from-bread-basket-to-basket-case-or-is-it-again-a-bit-morecomplicated/.

Severiano, F.A.A., 2011, 'The determinants of FDI in Portugal: A sectoral approach', pp. 1-71, Master science in economics dissertation, Católica University of Lisbon.

Siphambe, H.K., 2004, 'Botswana's economy and labour market: Are there any lessons for SADC regional integration?' Development Southern Africa 21(2), 353-364.

Tapera, J., 2016, 'African industrial revolution and strategies for attracting foreign direct investment for sustainable economic growth \& development in African Countries: The Zimbabwean case', International Journal of Economics, Commerce and Management 44, 31-43.

Tole, L. \& Koop, G., 2011, 'Do environmental regulations affect the location decisions of multinational gold mining firms?' Journal of Economic Geography 11(1), 151-177.

Zimbabwe Consolidated Diamond Company (ZCDCO), 2019, 'Annual Report', Harare, Zimbabwe.

Zimbabwe Environmental Law Association, 2016, Mineral revenue disclosure and the information needs of various stakeholders: A gap analysis, viewed 07 February 2019, from http://www.zela.org/download/mineral-revenue-disclosure-and-theinformation-needs-of-various-stakeholders-a-gap-analysis/.

Zimbabwe Independent, 2014, Recovery of mining sector key to long-term growth, viewed 18 March 2019, from https://www.theindependent.co.zw/2014/10/24/ recovery-mining-sector-key-long-term-growth. 